\title{
Nutrition of Patients with Jaw Fracture and After Orthognatik Surgery, Review of the Literature
}

\author{
Bobamuratova DT ${ }^{1 *}$, Boymuradov ShA ${ }^{2}$, Rakhmonov BB $^{3}$ and Olimjonov TA ${ }^{4}$ \\ ${ }^{1} \mathrm{PhD}$ Candidate (researcher), Department of Dentistry, Tashkent Medical Academy, Uzbekistan \\ ${ }^{2}$ Doctor of medical sciences, Department of Otolaryngology and Dentistry, head of the the maxillofacial surgery department of the \\ Tashkent Medical Academy, Uzbekistan \\ ${ }^{3}$ Master degree student of the department maxillofacial surgery, Tashkent State Dental Institute, Uzbekistan \\ ${ }^{4}$ master degree student of the department maxillofacial surgery, Tashkent State Dental Institute, Uzbekistan
}

Received: September 11, 2018; Accepted: September 28, 2018; Published: October 12, 2018

*Corresponding author: Bobamuratova DT, PhD Candidate (researcher), Department of Dentistry, Tashkent Medical Academy, Uzbekistan, 100109, Tel: +99897 7105911; E-mail: dbobamuratova@mail.ru

\begin{abstract}
Nutritional deficiencies occurring during treatment process in patients with jaw fractures will have a negative impact as: reducing of immune indicators in the body, weakening of protective reactions, tendency to complications, and traumatic effects.

This article summarizes the content of scientific studies related to the nutritional status or nutrition of patients with fractures.

METHODS: Was conducted a systematic review of randomized controlled trials evaluating the nutritional status of patients with jaw fractures and post-orthodontic surgery during immobilization.

Results: Were identified twenty-seven studies. It is established that during the immobilization period the patient has changes of the trophic status, nutritional insufficiency (malnutrition), explained by weight loss and changes in anthropometric parameters, blood changes (hypoalbuminemia, decrease of hemoglobin of blood).

Oral nutritional supplements or alternative feeding methods improve nutritional status, as many studies have observed (weight and other anthropometric parameters, normalization of biochemical blood parameters,). In addition, according to some authors, decreased the number of complications and reduced the duration of hospitalization and expenditure. It is recommended that nutritional supplements be offered to malnourished patients during this period.
\end{abstract}

Keywords: Maxillofacial trauma; Mandibular fracture; Jaw fracture; Nutrition; Feeding; Diet; Nutritional assessment; Nutritional status; Intermaxillar fixation; Orthognatik surgery;

\section{Introduction}

According to domestic and foreign authors, with maxillofacial injuries, fractures of the lower jaw occur in $70-85 \%$ of cases $[17,24,38,39]$. A nutritional disorder, which inevitably occurs in patients with trauma of the maxillofacial region, has a negative impact on the outcome of treatment.

In surgical patients, the operative insult is followed by a period of catabolism, characterized by release of stress hormones and inflammatory mediators. It is thought that if these physiological processes are unchecked or exaggerated, they will exacerbate the acute inflammatory response and contribute to morbidity. The following operation, surgical patients are vulnerable to the development and consequences of malnutrition, because of the mechanical restrictions imposed by their operations, pain, nausea, and periods.

Intermaxillary Fixation (IMF) is one of the modalities used in the fixation of the mandible to the maxilla after fracture reduction of these bones or any surgery to correct their position as in orthognathic surgery. The Intermaxillary Fixation (IMF) compromises the normal oral intake which leads to a situation similar to starvation or fasting state. This method is a constant stress for the patient, as it complicates speech and chewing. The diet of patients with IMF is restricted on a semisolid and fluid diet which is often inadequate in energy content and in the range of nutrients and this type of diet will not compensate the proteolysis process which occurs in response to trauma. Reducing energy consumption causes weight loss in subsequent changes in the composition of the body and muscles [16,25,31]. In many countries, despite the limitations, intermaxillary fixation is considered an absolute method of immobilization [7]. Conversely, IMF has also been used in obese patients for treatment obesity and diet control, and in these cases, body weight loss ranged 5-6 $\mathrm{kg} / 6$ weeks $[16,41]$.

However, patients who underwent orthognathic surgery also get bone trauma and IMF, as a rule, cannot eat properly for 6-8 weeks. It should be noted that during this period it is important to comply with all requirements for nutrition, otherwise, due to deficit of macro- and micronutrients, dehydration can develop unwanted complications [6,7].

Options to support oral nutrition or diet should meet the needs of patients, considering post-traumatic catabolism, 
blocking the chewing function and lack of function of the gastrointestinal tract $[5,17,21,24]$. As observations show, on trauma of the face and jaws, especially, penetrating to the oral cavity, the appetite decreases markedly, the taste is perversed, and the painfulness of the food intake procedure is quite natural. All this in the aggregate often causes the patients to refuse to eat or sharply limit themselves in eating [24]. With a prolonged lack of nutrition (with parenteral nutrition), it develops hypoxic damage to the mucosa of the gastrointestinal tract. These patients have intestinal insufficiency, as a rule, malabsorption develops due to a decrease in food intake, although it is during this period that the need for nutrients increases. Therefore, it can be said with certainty that patients with fractures in the maxillofacial area, undoubtedly, need temporary support of nutrition [2,9,14,21,24]

Poor nutrition, often unrecognized and untreated, causes muscular weakness, impaired immunity, and poor wound healing, and are associated with increasing in morbidity, and duration of hospitalization. In malnourished surgical patients, nutrition support improves nutrition status and clinical outcome.

The object of our review is to analyze the studies devoted to the nutritional features of patients with jaw fractures.

\section{Study Materials}

As a result of studying the literature, were selected patients with intermaxillary fixation. This also applies to patients after orthognathic surgery, because general and local features are similar to those in patients with jaw fractures in which immobilization lasts for a month. The articles were identified using the computerized search engine PubMed, Elsevier, Cochrane Central, Google scholar, Google search, Research Gate, Ebsco Host, dissercat.com, medical-diss.com and other possible sites with keywords: maxillofacial trauma, mandibular fracture, jaw fracture, intermaxillar fixation, orthognathic surgery and nutrition, feeding, diet, nutritional assessment, nutritional status, and in various combinations of these words in Russian and English. The relevant bibliographic lists were also taken into account. Were selected randomized controlled trials, metaanalyzes, and prospective clinical trials, on the basis of their significance.

\section{Results and Discussion}

Has been analyzed the work on the evaluation of malnutrition in the treatment of MFR trauma. The review identified 31 studies that highlight either nutritional status or the effectiveness of oral nutrient use in patients with jaw injuries. In the studies analyzed in this review, the nutritional status or effect of oral nutrients was assessed in patients with jaw fractures and in patients after orthognathic surgery (Table). In studies used the same or similar definitions to assess the nutritional status and risk for nutrition, but the inclusion criteria were different. 17 studies were in the form of an abstract, 11 journal articles and 3 thesis's.

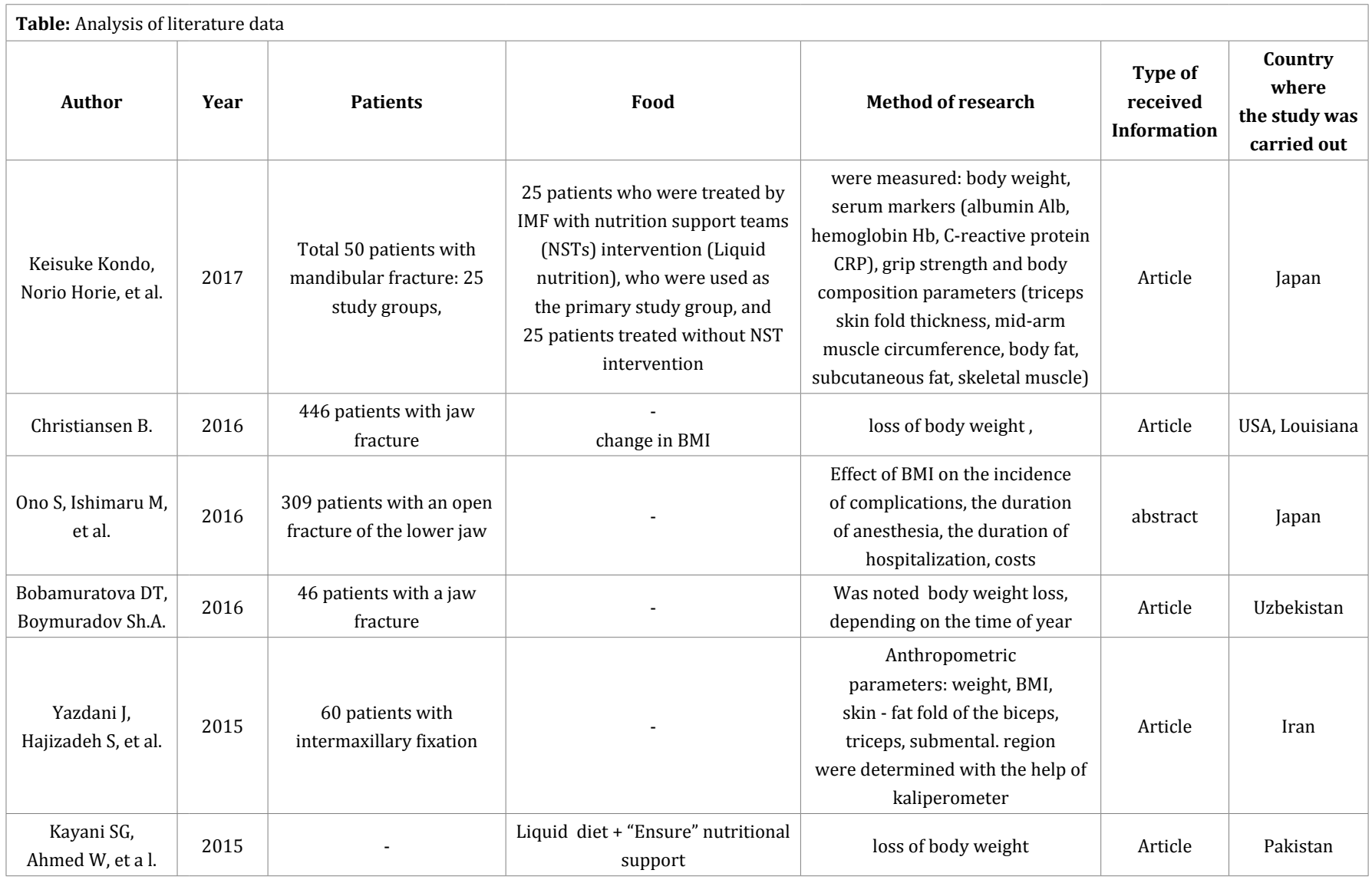




\begin{tabular}{|c|c|c|c|c|c|c|}
\hline $\begin{array}{l}\text { Malichly LA, } \\
\text { Ivchenko AP, et al. }\end{array}$ & 2015 & $\begin{array}{l}48 \text { patients of main } \\
\text { gr. with a fracture of the } \\
\text { lower jaw, } \\
44 \text { patients of control gr. }\end{array}$ & $\begin{array}{l}\text { In the main gr. nutritional } \\
\text { support with Nutri Drink }\end{array}$ & $\begin{array}{l}\text { The loss of body weight, changes } \\
\text { in anthropometric parameters: } \\
\text { the circumference of shoulders } \\
\text { and the thickness of skin fold } \\
\text { on and triceps, the level of } \\
\text { hemoglobin, total protein, albumin } \\
\text { in the blood }\end{array}$ & Abstract & Russia \\
\hline $\begin{array}{c}\text { Sheet W, Hassouni } \\
\text { MK }\end{array}$ & 2012 & $\begin{array}{l}25 \text { traumatized patients } \\
\text { and } 7 \text { obese patients }\end{array}$ & $\begin{array}{l}\text { Comparison between the } \\
\text { traumatized and obese patients. }\end{array}$ & $\begin{array}{c}\text { Body weight, } 4 \text { sites of skin } \\
\text { fold thickness. Laboratory } \\
\text { investigations included serum } \\
\text { electrolytes } \mathrm{Na}+1, \mathrm{~K}+1 \text { and serum } \\
\text { albumin levels }\end{array}$ & Article & Iraq \\
\hline $\begin{array}{l}\text { Kuvat SV, G ü ven } \\
\text { E, et al. }\end{array}$ & 2010 & 30 orthodontic patients & liquid + semi-liquid diet & $\begin{array}{l}\text { using a body composition } \\
\text { analyzer determined the } \\
\text { change in body weight, } \\
\text { fat mass, lean body mass, were } \\
\text { determined signs of nutritional } \\
\text { deficiency }\end{array}$ & Article & Turkey \\
\hline Mekkawy MM, et al. & 2010 & $\begin{array}{l}60 \text { patients with a jaw } \\
\text { fracture }\end{array}$ & $\begin{array}{l}\text { dietarian recommendations, } \\
\text { ration } \\
\text { change in hemoglobin level ; } \\
\text { trends of complications, } \\
\text { complaints, the intensity of pain }\end{array}$ & $\begin{array}{l}\text { assessment of nutritional } \\
\text { status using the } \\
\text { questionnaire «Mini Nutritional } \\
\text { assessment»/ BMI, }\end{array}$ & Article & Egypt \\
\hline Giacobbo J, et al. & 2009 & $\begin{array}{c}3 \text { cases after orthognathic } \\
\text { surgery }\end{array}$ & $\begin{array}{l}\text { high-calorie, high-protein } \\
\text { liquid }\end{array}$ & $\begin{array}{l}\text { body weight, anthropometric } \\
\text { parameters (BMI, shoulders } \\
\text { circumference, skin-fat fold of } \\
\text { triceps) }\end{array}$ & Article & Brazil \\
\hline Tegza NV. & 2008 & $\begin{array}{c}69 \text { patients with jaw } \\
\text { fracture }+69 \text { patients with } \\
\text { inflammatory diseases } \\
\text { of MFR }\end{array}$ & $\begin{array}{l}\text { Soft nonchewy diet + patients } \\
\text { with injuries - Nutrien OSteo, } \\
\text { patients with inflammatory } \\
\text { diseases of MFR - Nutrien } \\
\text { Standard }\end{array}$ & $\begin{array}{c}\text { anthropometric (BMI, PSZHO, } \\
\text { OMP), biochemical (protein: } \\
\text { general, albumen; nitrogen; lipids: } \\
\text { cholesterol, } \\
\text { carbohydrates: glucose, urine } \\
\mathrm{Na}, \mathrm{Ca} \text { ) ,leucocytes , erythrocytes; } \\
\text { Economic effectiveness of } \\
\text { treatment }\end{array}$ & $\begin{array}{l}\text { dissertation } \\
\text { Candidate } \\
\text { of Medical } \\
\text { sciences }\end{array}$ & Russia \\
\hline Telnikh RY. & 2008 & $\begin{array}{l}100 \text { patients with open } \\
\text { traumatic fractures } \\
\text { of the lower jaw: } 40 \\
\text { patients with traditional } \\
\text { scheme of managing; } 60 \\
\text { patients + dietary } \\
\text { supplements } \\
\text { and immunostimulatory } \\
\text { drug }\end{array}$ & $\begin{array}{l}\text { Biologically active supplement: } \\
\text { «Camosten» } \\
\text { (microelements and essential } \\
\text { amino acids), "FluGone” } \\
\text { anti - inflammatory } \\
\text { biochem. study. (Ca ++, alkaline } \\
\text { phosphatase) in the blood; } \\
\text { periods of incapacity for work }\end{array}$ & $\begin{array}{l}\text { clinical (local complications), } \\
\text { microbiological (dysbacteriosis), } \\
\text { x-ray studies, timing of } \\
\text { consolidation of fragments; }\end{array}$ & $\begin{array}{l}\text { dissertation } \\
\text { Cand. Of } \\
\text { Medical } \\
\text { Sciences }\end{array}$ & Russia \\
\hline Elamin $\mathrm{N}$. & 2006 & 30 patients with splints & $\begin{array}{l}- \\
\text { bioch. parameters (triglycerides, } \\
\text { cholesterol, protein), } \mathrm{K}+\text {, trends } \\
\text { of complications and complaints } \\
\text { of patients }\end{array}$ & loss of body weight; & $\begin{array}{l}\text { dissertation } \\
\text { of master } \\
\text { degree }\end{array}$ & Sudan \\
\hline El Khatib K, GradelJ. & 2005 & $\begin{array}{c}111 \text { patients with fracture } \\
\text { of the lower jaw } \\
\text { nutrition with a } \\
\text { nasogastric tube, }\end{array}$ & $\begin{array}{l}81 \text { patients - } \\
30 \text { patients - oral nutrition }\end{array}$ & $\begin{array}{c}\text { the duration of } \\
\text { hospitalization, costs, } \\
\text { postoperative complications }\end{array}$ & Abstract & \\
\hline Reychter TE. & 2002 & $\begin{array}{l}134 \text { patients with a jaw } \\
\text { fracture }(66+68)\end{array}$ & $\begin{array}{l}\text { optimization of the soft, } \\
\text { nonchewy diet + calcium alginate } \\
\text { bioch. indicators (protein, } \\
\text { creatinine lipids, urea, Ca); timing } \\
\text { of consolidation of fragments }\end{array}$ & evaluation of rations; & Article & Russia \\
\hline
\end{tabular}

Citation: Bobamuratova DT, Boymuradov ShA, Rakhmonov SB, Olimjonov TA (2018) Nutrition of Patients with Jaw Fracture and 


\begin{tabular}{|c|c|c|c|c|c|c|}
\hline Manus R. e t al. & 2000 & $\begin{array}{l}93 \text { patients with a jaw } \\
\text { fracture }\end{array}$ & $\begin{array}{l}\text { Assessment of the nutritional } \\
\text { status of alcoholics and those who } \\
\text { consume illegal substances }\end{array}$ & $\begin{array}{l}\text { correlation between alcohol } \\
\text { and plasma aspartate } \\
\text { aminotransferase, lactate } \\
\text { dehydrogenase, ferritin level }\end{array}$ & Abstract & - \\
\hline Worrall SF. & 1994 & $\begin{array}{l}22 \text { patients: } 18 \text { - with } \\
\text { a fracture of jaw, } 4- \\
\text { ortognathic surgery }\end{array}$ & - & $\begin{array}{l}\text { Body weight, lean mass, total } \\
\text { body water with the help of the } \\
\text { determination of skin-fat fold; } \\
\text { comparison of a group parameters } \\
\text { of patients with intermaxillar } \\
\text { fixation and fixation with mini- } \\
\text { screws }\end{array}$ & abstract & UK \\
\hline Antila & 1993 & $\begin{array}{l}17 \text { oral surgical patients } \\
\text { with intermaxillary } \\
\text { fixation }\end{array}$ & $\begin{array}{c}9 \text { patients received nutritional } \\
\text { counseling, } 8 \text { +oral } \\
\text { supplementation }\end{array}$ & $\begin{array}{l}\text { Body weight and anthropometric } \\
\text { parameters, serum copper, } \\
\text { iron, selenium and bromide } \\
\text { concentrations }\end{array}$ & Abstract & Finland \\
\hline Califano L, et al. & 1992 & $\begin{array}{l}12 \text { patients with a trauma } \\
\text { of MFR, } 12 \text { patients with } \\
\text { a neoplasm of MFR }\end{array}$ & adequate enteral nutrition & $\begin{array}{l}\text { anamnesis; nitrogen balance; } \\
\text { water-electrolyte balance; } \\
\text { immunne parameters }\end{array}$ & Abstract & Italy \\
\hline Saber SK. & 1991 & - & $\begin{array}{l}\text { individualized nutrition } \\
\text { healing of wounds; } \\
\text { general condition }\end{array}$ & infection; & Abstract & \\
\hline Cawood & 1985 & $\begin{array}{l}100 \text { patients with a jaw } \\
\text { fracture }\end{array}$ & - & $\begin{array}{l}\text { change in body weight, depending } \\
\text { on the method of treatment; } \\
\text { comparison of group parameters } \\
\text { with intermaxillar fixation and } \\
\text { fixation with mini-screws }\end{array}$ & Abstract & USA \\
\hline $\begin{array}{l}\text { Olejko TD, } \\
\text { Fonseca RJ. }\end{array}$ & 1984 & Orthognatik surgery & $\begin{array}{l}\text { high-calorie liquid - pre-operative } \\
\text { (early) food }\end{array}$ & Changes in body weight & Abstract & USA \\
\hline Harju E, Pernu H. & 1984 & $\begin{array}{l}13 \\
\text { patients withorthognathic } \\
\text { surgery }\end{array}$ & - & loss of body weight; complications & Abstract & Finlandiya \\
\hline $\begin{array}{c}\text { Kendell BD, } \\
\text { Fonseca RJ, Lee M. }\end{array}$ & 1982 & $\begin{array}{l}24 \text { patients }(12+12) \text { with } \\
\text { ortognathic surgery }\end{array}$ & $\begin{array}{l}\text { high-calorie liquid + libitum; } \\
\text { blended food }\end{array}$ & Body weight, protein level & Abstract & USA \\
\hline Rudenko AT. & 1982 & 65 patients & Dry protein mixture & $\begin{array}{l}\text { nitrogen urine, vitamin } \\
\text { metabolism (C, B1, B2), symptoms } \\
\text { of changes in the digestive tract }\end{array}$ & Article & Russia \\
\hline Lange H, PodleschI. & 1981 & 40 patients & $\begin{array}{c}\text { ordinary diet }+ \text { Nutro Drip , probe } \\
\text { feeding, postoperative } 10 \text { - day } \\
\text { nutrition }\end{array}$ & $\begin{array}{c}\text { Duration of complications; body } \\
\text { weight; protein (albumen), } \\
\text { creatinine) } \mathrm{K}+\end{array}$ & Abstract & Germany \\
\hline Martin Ritzau & 1975 & 33 patients & - & $\begin{array}{c}\text { loss of weight ; overweight } \\
\text { patients to have a greater loss of } \\
\text { weight }\end{array}$ & Abstract & USA \\
\hline Byrne J. & 1970 & 5 cases & diet & loss of body weight & Abstract & USA, Chicago \\
\hline Smith J. & 1965 & - & balanced, enriched liquid & $\begin{array}{l}\text { analysis of micronutrients; } \\
\text { complications, diarrhea, changes } \\
\text { in the digestive tract organs }\end{array}$ & Abstract & \\
\hline Califano L, et al. & 1992 & $\begin{array}{l}12 \text { patients with a trauma } \\
\text { of MFR, } 12 \text { patients with } \\
\text { a neoplasm of MFR }\end{array}$ & Adequate enteral nutrition & $\begin{array}{c}\text { anamnesis; nitrogen } \\
\text { balance; water-electrolyte } \\
\text { balance; immune parameters }\end{array}$ & Abstract & Italy \\
\hline
\end{tabular}


In 12 studies, was studied the topological status and nutritional insufficiency was revealed in patients with jaw fractures, that in the process of treatment did not receive specific nutrients. The principle of the endpoint in these studies was weight and anthropometric changes during immobilization or biochemical blood indices [1,3,7,10-12,16,25,27,29,30,33].

A balanced diet containing the optimal number of kilocalories and essential nutrients is important for patients with bone damage to prevent complications, support healing and health. To correct the nutritional insufficiency of these patients, a hypercaloric and enriched diet was proposed [6,9,20-22,24,26,35,45,46]. In patients with splints, the needs were regulated by a dietitian. Dietary recommendations help to improve consumption by changing the intake of food (for example, enriching food, adapting the diet). In some studies, increased energy and / or protein intake was studied, as a result of which the effectiveness of treatment was higher than in the control group $[6,9,20-22,26,35,46]$.

A number of authors evaluated the influence of patented supplements in the form of dry and liquid nutrient mixtures, biologically active additives, which were used as nutritional support in patients with trauma FMA. The goal of food is to ensure the balance of energy, proteins, vitamins and microelements, resulting in a significant improvement in the clinical outcomes of patients with a trauma of MFR. The use of nutritive support or biologically active additives proved to be more effective than standard care $[2,4,8,15,17,18,23,28,32]$.

Many researchers note that patients received support in the simplest way: they used additives for feeding or enteral tubes. El-Khatib et al. compared the result of tube- feeding and oral nutrition. After analyzing the hospitalization duration and frequency of complications, the authors found the advantages of the usual type of nutrition in 111 patients with a jaw fracture after osteosynthesis [13].

Some authors recommend the prescription of nutritional support to surgical patients either before surgery or after surgery due to the severity of existing malnutrition or for the purpose of preventing postoperative complications and reducing the timing of wound healing. Early postoperative nutrition $(<24$ hours) significantly affects nutritional status and promotes faster recovery [42-44]. Long-term nutritional support was suggested by Fonseca et al., who recommended pre-operative, high-calorie nutrition to orthognathic patients to prevent weight loss and complications [8].

The most common in patients with jaw injuries is a change in body weight. An assessment of anthropometric indicators trends, such as body mass index, thickness of skin-fat folds of the triceps, biceps, etc., was carried out by many authors. Biochemical parameters, duration of hospitalization, the timing of wound healing or consolidation of fragments, the nature of complications, quality of life and functional status can serve both as criteria for assessing tropholigic status and confirming markers for the effectiveness of nutritional support.
In 16 studies, was provided information about the change in body weight in patients with traumas of maxilla facial area [1,3 ,5,11,13,15,16,21,24,26,27,29,31]. Christensen noted an average of $4.8 \pm 6.4 \mathrm{~kg}$ of body weight loss, according to Worall, this index varied by an average of 4.5 for 6 weeks; E. Harju observed $7.5 \pm 3.5$ $\mathrm{kg}$ of weight loss for the entire period wearing a bimaxillar splint $[3,11,30]$. Antila et al. reported that body weight loss during the IMF period in patients receiving nutritional counseling with and without oral supplementation was $3.8 \pm 2.7 \%$ and $6.0 \pm 3.8 \% / 4-6$ weeks, respectively [4]. In Keisukes' study, body weight loss with nutrition support teams intervention $(1.8 \pm 1.5 \mathrm{~kg}$ and $3.1 \pm 2.3 \%$ /3 weeks) was significantly lower than that without intervention (2.7 $\pm 1.4 \mathrm{~kg}$ and $4.6 \pm 2.4 \% / 3$ weeks) [46].

Worall and Cawood, comparing the nutritional status of patients depending on the method of treatment, found that in patients with bone fixation with miniplates and screws, nutritional insufficiency and weight loss were significantly less $[27,30]$. The loss of body weight affects both the composition of the body, and the ratio between lean body mass and fatty deposits. Simultaneously with the reduction in body fat, a significant loss of body proteins occurs, which leads to a decrease in muscle mass. S. Kuvat et al. And Keisuke and coauthors with the help of the body composition analyzer revealed a change between lean and fat mass in patients after correction of occlusion surgically and with mandibular fracture $[31,46]$.

Changes in the body mass index as a result of treatment in patients are reported in 9 studies [10,11,12,17,25,31,32]. Other authors for assessing trophological status used anthropometric measurements by assessing the thickness of the skin-fat fold of the triceps, the biceps, the submental region, and the circumference of the shoulder muscles $[12,17,32]$. It is shown that the effectiveness of nutritional support during the treatment period directly depends on the nature of the intervention [17,32].

A number of authors carried out biochemical studies to assess the insufficiency of macro- and micronutrients $[2,4,5,6,7,16,17,22$ $24,28,33,46]$. As a result, were analyzed the concentration and composition of proteins, lipids, carbohydrates in blood and urine, the level of vitamins and microelements, electrolyte imbalance and a number of enzymes such as aspartate aminotransferase, lactate dehydrogenase, alkaline phosphatase, etc.

As is known, in the process of bone healing the main role is played by protein and minerals. It has been established that in patients with insufficient nutrition, slow down wound healing and synostosis [9,34]. Has been identified the relationship between nutrition and local status, on which depend the timing of the consolidation of fragments and healing of wounds $[18,28]$.

The frequency and nature of complications in the injured with a jaw fracture with nutritional support was studied in 9 studies $[2,3,7,9,13,18,20,26,28]$. As the analysis of these studies has shown, specialists make attempts to significantly reduce the risk of complications in the treatment of patients with a fracture of the mandible, using for this purpose different types of diets or nutritional support. Less complications and relief of complaints 
at an earlier time was observed in the group of patients who received additional nutritional support $[2,26]$.

However, the available randomized controlled trials provide too little information about the cost of such treatment. In total, we found 3 studies in which were studied the financial side and duration of hospitalization $[10,13,17]$. Thus, N.V. Tegza found that the use of dry nutrient mix is justified from a medical and economic point of view, since it promotes faster activation of patients in the clinic and reduces the cost of their maintenance in a hospital [17].

In another study, was considered the effect of a postoperative type of diet - hospital costs, depending on the frequency of complications [13]. Savings from shortening the duration of hospital stay were assessed by S. Ono et al., who found the relationship between the body mass index and the rate of complications, the duration of anesthesia, the duration of hospitalization, and the cost of treatment in 309 patients with an open fracture of the mandible [10].

\section{Conclusions}

i. As shown by the analysis of literature data, intermaxillary fixation and trauma itself have a significant effect on nutritional status and other metabolic indicators, such as body composition, including proteins, fats, carbohydrates, electrolytes, etc.

ii. The authors of many studies included in this review focus on the trophic status and the impact of an alternative strategy for feeding patients with jaw fractures and intermaxillary fixation.

iii. Recently, have been widely used the most modern methods for assessing trophological status, such as bioimpedanceometry, dual-energy X-ray absorptiometry, air plethysmography, MRI or magnetic resonance spectroscopy. Together, these methods make it possible to determine the structure of the body relatively accurately at the elemental, molecular, cellular, tissue levels and at the level of the organism as a whole. With the help of these methods, it is possible to determine the amount of fats, the weight without fat, the content of bone mineral substances, total body water, extracellular water, total adipose tissue and its internal depot (visceral, subcutaneous and intermuscular), skeletal muscles, ectopic fat depot giving information about the metabolic function. The use of technology to evaluate body composition is the most accurate method, but it is most effective when included as one of several important components of the study in assessing nutritional status.

Thus, the study of the nutritional status of the injured with a jaw trauma makes possible to determine the measures for correcting disorders and metabolic indices.

\section{References}

1. Boymurodov ShA, Bobamuratova DT, Kurbonov YeX. Change in weight of patients with jaw fracture depending on the seasons. Stomatology (Tashkent). 2016;2:69-74.

2. Lange $\mathrm{H}$, Podlesch I. Trials with the native physiological tube-feeding diet Nutro-Drip after maxillofacial operations. Infusionsther Klin Ernahr. 1981;8(6):291-301.

3. Harju E, Pernu H. Weight changes after jaw fixation due to sagittal split ramus osteotomy for correction of prognathous. Resuscitation. 1984;12(3):187-191.

4. Antila H, Salo M. Nanto V, Forssell K, Salonen M, Kirvela O. The effect of intermaxillary fixation on leukocyte zinc, serum trace elements and nutritional status of patients undergoing maxillofacial surgery. Clin Nutr. 1993;12(4):223-229.

5. Falender LG, Lebanon SG, Williams FA. Postoperative nutritional support in oral and maxillofacial surgery. J Oral Maxillofac Surg. 1987;45(4):324-330.

6. Kendell BD, Fonseca RJ, Lee M. Postoperative nutritional supplementation for the orthognathic surgery patient. J Oral Maxillofac Surg. 1982;40:205-213.

7. Elamin Nimir. Some physiological changes following intermaxillary fixation. Thesis is presented in partial fulfillment for the requirements of the degree of MSc. Sudan. 2006:10-15.

8. Olejko TD, Fonseca RJ. Preoperative nutritional supplementation for the orthognathic surgery patient. J Oral Maxillofac Surg. 1984;42(9):573-577.

9. Saber SK. Nutritional management of intermaxillary fixation patients. Adv Clin care. 1991;6(5);24-25.

10. Ono S, Ishimaru M, Ono Y, Matsui H, Fushimi K, Yasunaga H. Impact of Body Mass Index on the Outcomes of open reduction for mandibular fractures. J Oral Maxillofac Surg. 2016;74(5):1024.e1-1024.e5. doi: 10.1016/j.joms.2016.01.008

11. Christensen B, Kind BJ. The effect of mandibular fracture treatment on nutritional status. J Oral Maxillofac Surg. 2016:74(9):e30.

12. Yazdani J, Hajizadeh S, Ghavimi MA, Pourghasem Gargari B, Nourizadeh A, Kananizadeh Y. Evaluation of changes in anthropometric indexes due to intermaxillary fixation following facial fractures. J Dent Res Dent Clin Dent Prospects. 2016;10(4):247-250. doi: 10.15171/ joddd.2016.039

13. El Khatib K, Gradel J, Danino A, Mouaffak M, Malka G. Enteral feeding by nasogastric tube in mandibular fracture osteosynthesis. Rev Stomatol Chir Maxillofac. 2005;106(1):13-15.

14. Raymond F, Dexter Barber H, Powers M, David EF. Oral and Maxillofacial trauma. 4th edition. 2013;33:752.

15. Kayani SG, Ahmed W, Farooq M, Rehman AU, Nafees Q Baig AM. Weight loss due to maxillomandibular fixation in mandibular fractures. Pak Oral Dent J. 2015;35(3):374-376.

16. Sheet W, Hassouni MK. Changes in body weight, serum (Sodium, Potassium) and serum albumin after intermaxillary fixation in 
traumatized and obese patients (Comparative Study). Al Rafidain Dent J. 2012;12(1):52-56.

17. Tegza NV. Medico-economic justification for the use of dry nutrient mixtures in the nutrition of servicemen with injuries and diseases of the maxillofacial region in medical institutions of the Ministry of Defense of the Russian Federation. Dis. Candidate of medical sciences. 2008;32.

18. Telnykh RYu. The use of biologically active food additives in the complex treatment of open traumatic fractures of the lower jaw- Diss. Candidate of medical sciences. 2008;30.

19. Manus RC Jr, Dodson TB, Miller EJ Jr, Perciaccante VJ. Nutritional status of substance abusers with mandible fractures. J Oral Maxillofac Surg. 2000;58(2):153-157.

20. Smith J. Nutritional maintenance of the oral fracture patient. Oral Surg Oral Med Oral Pathol. 1965;9(6):705-710.

21. Byrne JE, Lynne RB. The dietary management of the patient with a fractured jaw. Oral Surg Oral Med Oral Pathol. 1970;29(5):666-675.

22. Califano L, Zupi A, Giardino C. Enteral nutrition in maxillo-facial surgery. Rev Stomatol Chir Maxillofac. 1992;93(6):388-392.

23. Rudenko AT, Buznik IM, Zablin VP. Efficacy of protein enpate in the treatment of patients with maxillofacial trauma. Military-medical journal. 1982;7:29-32.

24. Kabakov BD, Rudenko AT. Kabakov BD. Nutrition of patients with facial and jaw injuries and caring for them. Medicine. 1977;135.

25. Giacobbo J, Mendel MIL, Borges WD, El-Kik RM, Oliveira RB, Silva DN. Assessment of nutritional anthropometric parameters in adult patients undergoing orthognathic surgery. Rev odonto ciênc. 2009;24(1):92-96.

26. Mekkawy MM, Azer SZ, El Gamil A. Impact of implementing nutritional therapy protocol on prevention of weight loss among mandibular fracture patients. Impact of Implementing Nutritional. 2015;10(1).

27. Cawood JI. Small plate osteosynthesis of mandibular fractures. Br J Oral Maxillofac Surg., 1985;23(2):77-91.

28. Fedotov SN, Raykher TE. Biochemical blood indices in the inhabitants of the European North with fractures of the mandible, depending on nutrition. Stomatology (Mocow). 2002;81(2):11-14.

29. Ritzau M. Weight changes in patients with intermaxillary immobilization after jaw fractures. Int J Oral Surg. 1973;2(3):122-123.

30. Worrall SF. Changes in weight and body composition after orthognathic surgery and jaws fractures: a comparison of miniplates and intermaxillary fixation. Br J Oral Maxillofac Surg. 1994;32(5):289292.

31. Kuvat SV, Güven E, Hocaoqlu E, Bazaran K, Marzan G, Cura N, et al. Body fat composition and weight changes after double-jaw osteotomy. J Craniofac Surg. 2010;21(5):1516-1518. doi: 10.1097/ SCS.0b013e3181f03fb3
32. Malychly LA, Ivchenko AP, Nesterov AA, Kuchkina ES, Kitiashvili DI. Correction of the main indicators of nutritional status in patients with fractures of the lower jaw. Collection. 2016:67-68.

33. Semenova Dutov, Pinelis IS. Influence of the orthopedic method of fixing fragments on the change in biochemical indicators of bone tissue metabolism in the fracture of the lower jaw. Far Eastern Medical Journal. 2013;4:71-74.

34. Williams JZ, Barbul A. Nutrition and wound healing. Surg Clin. 2003;83(3):571-596.

35. Hamid HE, Azlina A, Igzeer YK. The role of protein deficiency in the healing of mandibular fractures in rabbit model. International $\mathrm{j}$ of pharmacy and pharmaceutical sciences. 2014;6(2):352-357.

36. Walley J, Andrus J, Charles FT, John S. Effect of nutrition, diet and suture. Annals of surgery. 1975;182(2):93-97.

37. Gordon PE, Lawler ME, Kaban LB, Dodson TB. Mandibular fracture severity and patient health status are associated with postoperative inflammatory complications. J Oral Maxillofac Surg. 2011; 69(8):21912197. doi: 10.1016/j.joms.2011.03.071

38. Izosimov AA. Optimization of complex treatment of the mandible fractures. Abstract of dissertation candidate of med sciences. Perm. 2007;32.

39. Yefimov YV. Fractures of the lower jaw and their complications. Abstract of dissertation candidate of med sciences. 2004;28.

40. Bezrukova VM, Robustia TG. Manual on surgical dentistry and maxillofacial surgery. 2000:497:535-536.

41. Behbehani F, Al-Aryan H, Al-Attar A, Al-Hamad N. Perceived effectiveness and side effect of intermaxillary fixation for diet control. Int J Oral Maxillofac Surg. 2006;35(7):618-623.

42. Minard G, Kudsk K, Melton S, Patton JH, Tolley EA. Early versus delayed feeding with an immune-enhancing diet in patients with severe head injuries. Journal of Parenteral and Enteral Nutrition. 2000;24(3):145149.

43. Maynard ND, Bihari DJ. Postoperative feeding. BMJ. 1991;303(6809):1007-1008. [MEDLINE: 1991320073]

44. Moore FA, Feliciano DV, Andrassy RJ, McArdle AH, Booth FV, Morgenstein-Wagner TB, et al. Early enteral feeding compared with parenteral, postoperative septic complications. The results of a metaanalysis. Ann Surg. 1992;216(2):172-183.

45. Califano L, Zupi A, Giardino C. Enteral nutrition in maxillo-facial surgery. Rev Stomatol Chir Maxillofac. 1992;93(6):388-392.

46. Kondo K, Horie N, Ohmuro M, Sato M, Tokuyama M, Muroya T, et al. Nutritional Support Team Intervention for Patients with Mandibular Fracture Treated by Intermaxillary Fixation. J Trauma Treat. 2017;6:402. 